\title{
Development of an Instrument for Enterprise Resource Planning (ERP) Implementation in Indian Small and Medium Enterprises (SMEs)
}

\author{
R. M. Bhawarkar \\ Training \& Placement Officer, \\ Acharya Shrimannarayan Polytechnic, Wardha. \\ Maharashtra, India.
}

\author{
L. P. Dhamande \\ Phd,Principal, \\ COET, Dhamangaon - Rly. \\ Distt- Amravati. \\ Maharashtra, India.
}

\begin{abstract}
In India, majority of companies have had nothing but disaster with ERP implementation projects. Much has been written on implementation of Enterprise Resource Planning (ERP) system in organizations of various sizes. Implementing an ERP system is a difficult and high cost proposition as it places tremendous demands on organization's resources and time. Very few studies have scientifically developed and tested constructs that represents critical success factors for ERP implementation projects. Global competition and economic liberalization are creating opportunities and posing challenges in front of the Indian Industries. In this paper, we discover and classify critical success factors for ERP implementation in Indian Small \& Medium size Enterprises (SMEs), presents a pilot study aim at developing an instrument for ERP in Indian small \& medium scale Enterprises (SME's). An extensive literature review was carried out for identification of various attributes which grouped in various critical success factors (CSF's). The instrument consisting of 23 variables was identified after literature review. A 24 item questionnaire was developed from the relevant literature and distributed to 863 SME's. Data from 219 SMEs were collected for the measurement of effectiveness of these critical success factors. Through the study, four factors were identified that attempts to explain $84.203 \%$ of variances that impact ERP Implementation. The factors are found to be reliable and valid. We believe that the comprehension of these factors will deepen the understanding of ERP implementation and will help to avoid implementation mistakes, thereby increasing the rate of success.
\end{abstract}

\section{Keywords}

Enterprise Resource Planning (ERP), Critical Success Factors (CSFs), Small and Medium Size Enterprises (SMEs).

\section{INTRODUCTION}

Small and medium sized enterprises (SME's) are of critical importance to many economics as well as industrial development of the country. While SME's are integral part of these economics, they also face numerous challenges in implementing technologies such as Enterprise resource Planning (ERP) systems, including a lack of human \& financial resources to support such initiatives [29]. Technology has had a major impact on every organization. Whether it is a small or large organization, being competitive is the key to success. Issue in dealing with a new ERP system is not solely technology, but it involves high degree of planning and commitment too. SMEs face many of the same competitive problems as larger organizations, but have limited resources, experience \& staffing skills. Like many other technological advances, ERP systems were initially implemented mostly at large organizations. Their relative absence from SMS's has probably been the main reason for the research focus on large companies. More recently, however, vendors began to provide SME-specific ERP's. ERP adoption at SME's has been catching up with large companies [27].

The organizations which have successfully implemented the ERP systems are reaping the benefits of having integrating working environment, standardized processes and operational benefits to the organization. Not all ERP implementation have been successful. Some of the reasons of improper implementation of ERP cited in the literature are lack of support of top management, resistance from employees, poor selection of ERP software and vendor etc. Most of the studies have used case studies to conclude their findings and very few have used the empirical to study the ERP. The objective of this paper is to develop an instrument for measuring ERP implementation critical success factors. In this paper, first, we review the literature mainly to identify ERP critical success factors (CSF's) in general organizations. Next, we describe the data collection, then we present and discuss the factors that emerged and finally, we present the study contribution and conclusion. The study reveals that about $84.203 \%$ of the variances in ERP implementation were explained by the critical factors identified in the study.

\section{LITERATURE REVIEW}

Extensive literature review was carried out for identification of various attributes of ERP which were grouped into the critical success factors (CSF's). Critical success factors have been used significantly to present or identify a few key factors that organizations should focus on to be successful. As a definition, critical success factors refer to "the limited number of areas in which satisfactory results will ensure successful competitive performance for the individual, department or organization". Table 1 presents a list of variables selected by author from the literature review. 
Table 1: List of variables selected from review.

\begin{tabular}{|ll|ll|}
\hline 1. & Top management support & 2. & Project team competence \\
\hline 3. & Interdepartmental cooperation & 4. & Clear goal and objectives \\
\hline 5. & Project Management & 6. & $\begin{array}{l}\text { Interdepartmental } \\
\text { Communication }\end{array}$ \\
\hline 7. & $\begin{array}{l}\text { Appropriate management of } \\
\text { expectations }\end{array}$ & 8. & Project champion \\
\hline 9. & Vendor support & 10. & $\begin{array}{l}\text { Careful package } \\
\text { selection }\end{array}$ \\
\hline 11. & Data analysis and conversion & 12. & Dedicated resources \\
\hline 13. & Steering committee & 14. & User Training \\
\hline 15. & $\begin{array}{l}\text { Education on new business } \\
\text { processes }\end{array}$ & 16. & $\begin{array}{l}\text { BPR ( Business process } \\
\text { re-engineering) }\end{array}$ \\
\hline 17. & Minimal customization & 18. & Architecture choices \\
\hline 19. & Managing Cultural Change & 20. & Change management \\
\hline 21. & Vendor partnership & 22. & Vendor tools \\
\hline 23. & Use of consultants & & \\
\hline
\end{tabular}

\section{RESEARCH METHODOLOGY}

This research was a cross sectional field study that involved the use of survey methodology to obtain data from small \& medium scale industries across a variety of production environments. A model was developed to include key variables and their relationships in the implementation of ERP system. A questionnaire was developed to collect data from Indian SMEs, for testing these relationships. The survey was implemented using a mixed - mode method wherein postal mail procedures were mixed with email delivery.

\section{DEVELOPMENT OF RESEARCH MODEL}

Research is a systematized effort to gain new knowledge and to gain knowledge, data is required. From the collected data's, models are developed. Development of model is not a simple process. Most of the instruments were developed in the social science by the psychologists. General psychological principles were used to develop the research instrument for this study. Figure 1 shows the instrument development process [42].

\section{IDENTIFICATION AND FINAL SELECTION OF CRITICAL SUCCESS}

Factors are the areas where organizations have to focus on to gain the profit. Critical success factors, which are important and essential for successful implementation of any management system in an organization to gain the profit. The variables are collected from the extensive literature review. Which are then group into the different factors by carrying out the factor analysis. These are the critical success factors which help management to obtain better understanding of enterprise resource planning (ERP) and allow researchers to proceed with the task of developing and testing theories. In our study, total 23 variables were identified through the extensive literature review. These attributes help management to identify those areas where improvement can be made. The identified variables are listed in section 2 (literature review).

\section{SURVEY METHODOLOGY}

Invitations to participate in the survey requested responses from implementers of ERP packages who have basically worked for small \& medium scale enterprises based in India and have been associated with the implementation process for their respective organization. Questionnaire survey method was selected and used five point multi-items, liker-type scales

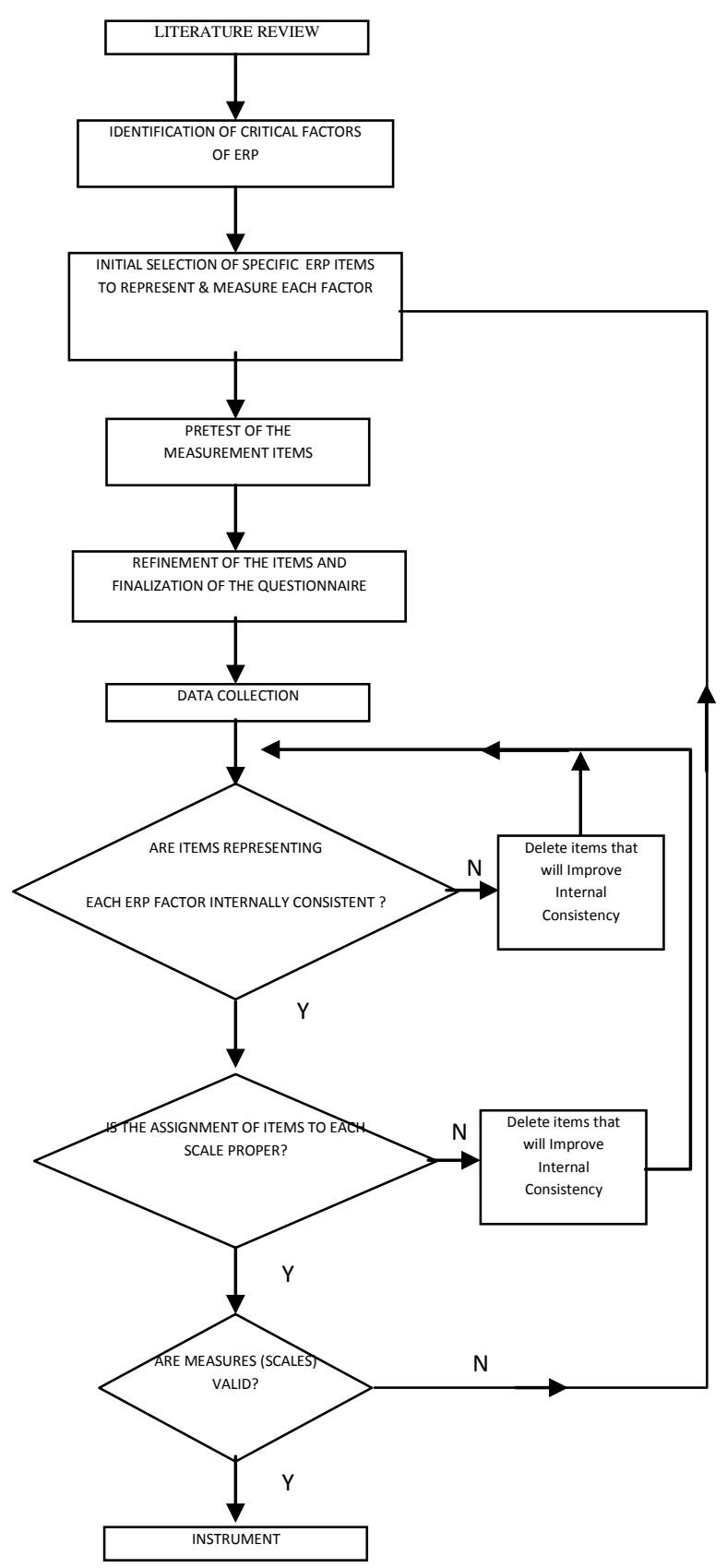

Fig. 1 The Instrument Development Process (Source : Saraph et al, 1989).

for each item where ' 1 ' meant 'not important', '2' meant 'somewhat important,, '3' meant "neutral', '4' meant

'important' and ' 5 ' meant 'most important'. The questionnaire is focused on the importance of CSF's that clarified from literature review. It identifies the respondents perception of the importance of CSF's in the ERP implementation process. 


\section{ANALYSIS}

An analysis is conducted to defect weaknesses in design and instrumentation and to provide proxy data for selection of a probability data. By carrying out the extensive literature review total 23 variables were framed in the research instrument (questionnaire). The main objective of this study is to identify the current ERP scenario in small and medium scale enterprise. Accordingly, to draw meaningful conclusion, sample frame \& sample size were decided based on review. Sample frame consist of the all type of small and medium scale enterprises. The questionnaire was sent to 863 organizations \& 219 usable surveys were received making the response rate to be around $25.37 \%$. The respondents came from manufacturing, financial services, healthcare, Insurance, process oriented, unit oriented, public service, telecommunication, utility \& a variety of other industries.

\subsection{Reliability of Instrument}

Reliability is one of the most critical elements in assessing the quality of the construct measures [15], and it is necessary condition for scale validity. A statistically reliable scale provides consistent and stable measures of a construct. There are four methods to measure the reliability of empirical model out of these four, internal consistency method is easy and works effectively in the field studies.

The internal consistency of a set of measurement variables is to the degree to which items in the set are homogeneous. Internal consistency can be estimated using reliability coefficient such as Cronbach's alpha [18]. With the objective of establishing the reliability of the data collected and that of the study. Cronbach's alpha of tha data pertaining to the factors was calculated. Nunnally (1971) suggests that a Cronbach's alpha value larger than 0.7 suggests good internal consistency. The overall Cronbach's alpha for independent variable was found to be 0.968 indicates that the developed model was found to be reliable. Table 2 shows the reliability statistics of input variables, whereas Table 3 shows the reliability for four critical Success factors.

Table 2: Reliability Statistics (Input Variables) Reliability Statistics

\begin{tabular}{|c|c|c|}
\hline $\begin{array}{c}\text { Cronbach's } \\
\text { Alpha }\end{array}$ & $\begin{array}{c}\text { Cronbach's Alpha Based on } \\
\text { Standardized Items }\end{array}$ & N of Items \\
\hline .968 & .967 & 23 \\
\hline
\end{tabular}

Table 3: Internal Consistency - Reliability for four Critical Success Factors (Input Factors)

\begin{tabular}{|c|l|c|c|}
\hline $\begin{array}{c}\text { Sr. } \\
\text { No }\end{array}$ & Factor Name & $\begin{array}{c}\text { Cronbach } \\
\text { Alpha }\end{array}$ & $\begin{array}{c}\text { No. of } \\
\text { Items }\end{array}$ \\
\hline 1 & Approach & 0.982 & 7 \\
\hline 2 & $\begin{array}{l}\text { Culture, Communication } \\
\text { \& Support }\end{array}$ & 0.957 & 6 \\
\hline 3 & Project Management & 0.957 & 5 \\
\hline 4 & $\begin{array}{l}\text { Vision, Scope, Goal \& } \\
\text { Infrastructure }\end{array}$ & 0.904 & 5 \\
\hline
\end{tabular}

\subsection{Descriptive Statistics for Variables}

The primary data analysis involved the use of descriptive statistical tools such as mean and standard deviation. These measures were utilized to know the data quality. The mean and standard deviation associated with each scale used to measure the critical success factors facilitating ERP system deployment are shown in table 4 . All the 23 variables showing minimum mean valve of $3.85 \&$ a maximum mean valve of 4.3973 , which means that most of the mean values are more than 4 and others are nearer to 4 . It shows the perception of Indian small \& medium ERP firms towards these 23 factors that means these factors were critical for the successful ERP implementation.

Table 4: Descriptive Statistics of Responses of CSFs.

\begin{tabular}{|l|r|r|r|}
\hline \multicolumn{4}{|c|}{ Descriptive Statistics } \\
\hline & \multicolumn{1}{|c|}{$\mathrm{N}$} & \multicolumn{1}{c|}{ Mean } & \multicolumn{1}{c|}{$\begin{array}{c}\text { Std. } \\
\text { Deviation }\end{array}$} \\
\hline Top Management Support & 219 & 4.3973 & .71817 \\
\hline $\begin{array}{l}\text { Interdepartmental } \\
\text { Cooperation }\end{array}$ & 219 & 4.2694 & .82146 \\
\hline Project Team Competence & 219 & 4.2009 & .78155 \\
\hline $\begin{array}{l}\text { Interdepartmental } \\
\text { Communication }\end{array}$ & 219 & 4.19 & .866 \\
\hline Vendor Support & 219 & 4.17 & .869 \\
\hline Clear Goal \& Objectives & 219 & 4.08 & .829 \\
\hline Architecture Choices & 219 & 4.05 & .983 \\
\hline $\begin{array}{l}\text { Appropriate Management } \\
\text { Of Expectations }\end{array}$ & 219 & 4.04 & .809 \\
\hline Project Management & 219 & 4.04 & .834 \\
\hline $\begin{array}{l}\text { Education On Business } \\
\text { Processes }\end{array}$ & 219 & 4.03 & .945 \\
\hline Managing Cultural Change & 219 & 4.03 & .976 \\
\hline $\begin{array}{l}\text { BPR (Business Process Re- } \\
\text { engineering) }\end{array}$ & 219 & 4.00 & .843 \\
\hline Use Of Consultants & 219 & 4.00 & 1.062 \\
\hline User Training & 219 & 4.00 & .995 \\
\hline $\begin{array}{l}\text { Data Analysis \& } \\
\text { Conversion }\end{array}$ & 219 & 4.00 & .875 \\
\hline Vendor Tools & 219 & 3.98 & 1.053 \\
\hline Minimal Customization & 219 & 3.98 & 1.040 \\
\hline Project Champion & 219 & 3.97 & .818 \\
\hline Change Management & 219 & 3.97 & 1.053 \\
\hline Careful Package Selection & 219 & 3.92 & .869 \\
\hline Steering Committee & 219 & 3.90 & .886 \\
\hline Dedicated Resources & 219 & 3.89 & .897 \\
\hline Vendor Partnership & 219 & 3.85 & .975 \\
\hline Valid N (listwise) & 219 & & \\
\hline & & & \\
\hline
\end{tabular}

\subsection{Factor Analysis}

An exploratory factor analysis was conducted on the different measures to purify the model. Factor analysis is most frequently used to identify a small number of factors, which may be used to represent relationship among sets of interrelated variables. Factor analysis is frequently used to develop questionnaires. In this study, factor extraction principal components method was used with original 23 independent variables.

The first step is to decide which factors you wish to retain in the analysis. The common sense criterion for retaining factors is that each retains factors must have some sort of face validity or theoretical validity. The SPSS V 18 default is to keep any factor with an Eigen value larger than 1.0. If a factor less than 1.0, it explains less variance than an original variables and usually for only a few of the factors will the Eigen value be larger than 1.0 there are other criteria for selection such as Scree plot or conceptual reasons that may be used. The Scree plot sometimes used to select how many 
factors to rotate to a final solution. The traditional construct for interpretation is that the Scree should be ignored and that only factors on the steep portion of the graph should be selected and rotated. We have selected 4 input factors (independent) based on the observation of the Scree plot (Fig 2). Also, the Eigen value of these variables are lower than 0.4 .

After factor extraction and the rotation, loading of the variables in respective factor was noted down and the naming was done. Table 3 shows the reliability of (internal consistency) co- efficient of input factor which ranged from 0.904 to 0.982 . Table 5 shows the rotated component matrix.

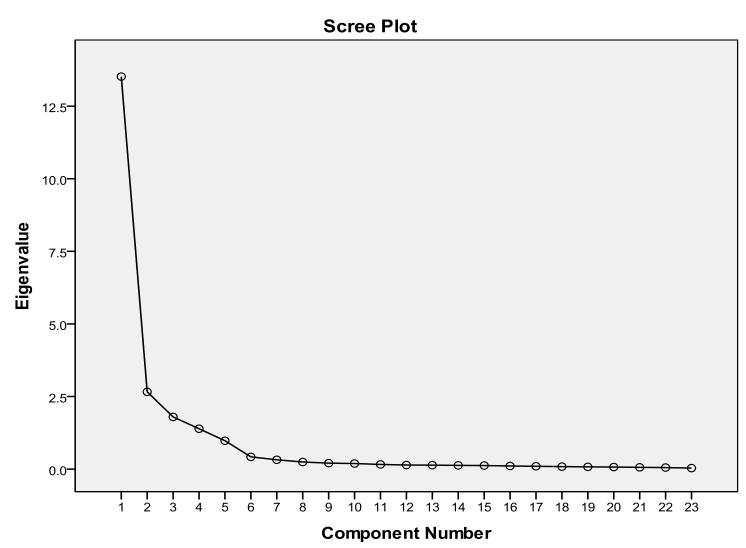

Fig. 2 Scree Plot.

Table 5: Rotated Component Matrix for CSFs (Independent Factors).

\begin{tabular}{|l|c|c|c|c|}
\hline \multicolumn{5}{|c|}{ Rotated Component Matrix } \\
\hline & \multicolumn{4}{|c|}{ Component } \\
\hline & 1 & 2 & 3 & 4 \\
\hline 18-Architecture Choices & .836 & & & \\
\hline 23-Use Of Consultants & .834 & & & \\
\hline $\begin{array}{l}\text { 15-Education On New } \\
\text { Business Processes }\end{array}$ & .832 & & & \\
\hline 14-User Training & .824 & & & \\
\hline 22-Vendor tools & .823 & & & \\
\hline 20-Change Management & .820 & & & \\
\hline 17-Minimal Customization & .812 & & & \\
\hline $\begin{array}{l}\text { 3-Interdepartmental } \\
\text { Cooperation }\end{array}$ & & .887 & & \\
\hline 1-Top Management Support & & .869 & & \\
\hline 2-Project Team Competence & & .848 & & \\
\hline $\begin{array}{l}\text { 6-Interdepartmental } \\
\text { Communication }\end{array}$ & & .841 & & \\
\hline 9-Vendor Support & & .840 & & \\
\hline 19-Managing Cultural Change & & .793 & & \\
\hline 8-Project Champion & & & .874 & \\
\hline $\begin{array}{l}\text { 11-Data Analysis \& } \\
\text { Conversion }\end{array}$ & & & .872 & \\
\hline 13-Steering Committee & & & .854 & \\
\hline 5-Project Management & & & .811 & \\
\hline 21-Vendor partnership & & & .787 & \\
\hline 4-Clear Goal \& Objectives & & & & .858 \\
\hline
\end{tabular}

\begin{tabular}{|c|c|c|}
\hline $\begin{array}{l}\text { 7-Appropriate management } \\
\text { Of Expectations }\end{array}$ & & .840 \\
\hline $\begin{array}{l}\text { 16-BPR (Business Process } \\
\text { Re-engineering) }\end{array}$ & & .798 \\
\hline 12-Dedicated Resources & & .547 \\
\hline 10-Careful Package Selection & .404 & .526 \\
\hline \multicolumn{3}{|c|}{$\begin{array}{l}\text { Extraction Method: Principal Component Analysis. } \\
\text { Rotation Method: Varimax with Kaiser Normalizatio }\end{array}$} \\
\hline
\end{tabular}

\subsection{Interpretation of Output From the Factor Analysis of CSFs or Factor Naming}

After factor analysis four factors were extracted this explained total $84.203 \%$ of variances which were named as shown in table 6 as per the variables content within that component

\section{DETAILED ITEM ANALYSIS}

This method is used to evaluate the assignment of variables to scales as per Nunnally's method (1971). As per this method variable should have high co-relation with the scale in which the variable is placed than other scales. As seen in table 7, all the variables have high co-relations with the scales to which they had been assigned relative to all others. Therefore it was concluded that all the variables in this instrument had been correctly assigned to respective scale.

\section{VALIDITY}

The validity of a measure refers to the extent to which it measures what is intended to be measured. There are two different types of validity generally considered.

A. Content Validity: Content validity was subjectively judged by the researchers [42] contents of this instrument were selected based on the extensive literature reviews and discussed with experts and with recent literature regarding the implementation of ERP system in SME'S. Thus we said that this study have content validity.

B. Construct Validity: The construct validity of each measure was evaluated by factor analyzing the measurement items of each of the factors. A measure has construct validity if it the theoretical construct that it has design to measure. The factor matrices (Table 8) showed that all the input factors were unifactorial with Eigen values greater than the accepted criteria of 1 . The result of this study indicated good construct validity for the developed scales. 
Table 6: Interpretation of Output from the Factor Analysis of CSFs.

\begin{tabular}{|c|c|c|c|}
\hline $\begin{array}{l}\text { Categorization of CSFs in terms of } \\
\text { Component }\end{array}$ & TVE * & List of CSFs for Indian SMEs & $\mathbf{R C M V} *$ \\
\hline Component 1: Named as "Approach" & 58.774 & $\begin{array}{l}\text { 18-Architecture Choices } \\
\text { 23-Use Of Consultants } \\
\text { 15-Education On New Business Processes } \\
\text { 14-User Training } \\
\text { 22-Vendor tools } \\
\text { 20-Change Management } \\
\text { 17-Minimal Customization }\end{array}$ & $\begin{array}{l}.836 \\
.834 \\
.832 \\
.824 \\
.823 \\
.820 \\
.812\end{array}$ \\
\hline $\begin{array}{l}\text { Component 2: Named as "Culture, } \\
\text { Communication \& Support" }\end{array}$ & 11.572 & $\begin{array}{l}\text { 3-Interdepartmental Cooperation } \\
\text { 1-Top Management Support } \\
\text { 2-Project Team Competence } \\
\text { 6-Interdepartmental Communication } \\
\text { 9-Vendor Support } \\
\text { 19-Managing Cultural Change }\end{array}$ & $\begin{array}{l}.887 \\
.869 \\
.848 \\
.841 \\
.840 \\
.793\end{array}$ \\
\hline $\begin{array}{l}\text { Component 3: Named as "Project Management } \\
\text { ” }\end{array}$ & 7.814 & $\begin{array}{l}\text { 8-Project Champion } \\
\text { 11-Data Analysis \& Conversion } \\
\text { 13-Steering Committee } \\
\text { 5-Project Management } \\
\text { 21-Vendor partnership }\end{array}$ & $\begin{array}{l}.874 \\
.872 \\
.854 \\
.811 \\
.787\end{array}$ \\
\hline $\begin{array}{l}\text { Component 4: Named as "Vision, Scope, Goal } \\
\text { \& Infrastructure" }\end{array}$ & 6.043 & $\begin{array}{l}\text { 4-Clear Goal \& Objectives } \\
\text { 7-Appropriate management Of } \\
\text { Expectations } \\
\text { 16-BPR (Business Process Re-engineering) } \\
\text { 12-Dedicated Resources } \\
\text { 10-Careful Package Selection }\end{array}$ & $\begin{array}{l}.858 \\
.840 \\
.798 \\
.547 \\
.526\end{array}$ \\
\hline
\end{tabular}

*TVE - Total Variances Explained

*RCMV - Rotated Component Matrix Value 
Table 7: Detail Factor Analysis.

\begin{tabular}{|c|c|c|c|c|}
\hline \multicolumn{5}{|c|}{ Correlations } \\
\hline & $\begin{array}{l}\text { IN_SCORE1- } \\
\text { Approach }\end{array}$ & $\begin{array}{l}\text { IN_SCORE2-Culture, } \\
\text { Communication \& Support }\end{array}$ & $\mid \begin{array}{c}\text { IN_SCORE3- } \\
\text { Project Management }\end{array}$ & $\begin{array}{l}\text { IN_SCORE4- Vision, Scope, } \\
\text { Goal \& Infrastructure }\end{array}$ \\
\hline 18_Architecture Choices & $.942^{* * *}$ & $.555^{* * *}$ & $.510^{* * *}$ & $.601^{* * *}$ \\
\hline 23_Use Of Consultants & $.962^{* * *}$ & $.569^{* *}$ & $.555^{* *}$ & $.643^{* *}$ \\
\hline $\begin{array}{l}\text { 15_Education On New Business } \\
\text { Processes }\end{array}$ & $.923^{* *}$ & $.498^{* *}$ & $.515^{* *}$ & $.596^{* *}$ \\
\hline 14_User Training & $.936^{* *}$ & $.553^{* *}$ & $.494^{* *}$ & $.629^{* *}$ \\
\hline 22_Vendor tools & $.934^{* *}$ & $.523^{* *}$ & $.521^{* *}$ & $.629^{* *}$ \\
\hline 20_Change Management & $.935^{* * *}$ & $.528^{* * *}$ & $.488^{* * *}$ & $.638^{* *}$ \\
\hline 17_Minimal Customization & $.920^{* * *}$ & $.542^{* *}$ & $.492^{* * *}$ & $.634^{* * *}$ \\
\hline 3_Interdepartmental Cooperation & $.548^{* * *}$ & $.884^{* * *}$ & $.330^{* * *}$ & $.442^{* *}$ \\
\hline 1_Top Management Support & $.431^{* * *}$ & $.849^{* *}$ & $.268^{* * *}$ & $.401^{* *}$ \\
\hline 2_Project Team Competence & $.535^{* * *}$ & $.872^{* * *}$ & $.331^{* * *}$ & $.469^{* *}$ \\
\hline 6_Interdepartmental Communication & $.596^{* *}$ & $.883^{* *}$ & $.372^{* *}$ & $.471^{* *}$ \\
\hline 9_Vendor Support & $.577^{* * *}$ & $.885^{* * *}$ & $.368^{* *}$ & $.415^{* *}$ \\
\hline 19_Managing Cultural Change & $.600^{* * *}$ & $.863^{* *}$ & $.392^{* * *}$ & $.472^{* *}$ \\
\hline 8_Project Champion & $.522^{* * *}$ & $.423^{* *}$ & $.927^{* * *}$ & $.551^{* * *}$ \\
\hline 11_Data Analysis \& Conversion & $.544^{* *}$ & $.406^{* *}$ & $.923^{* * *}$ & $.537^{* *}$ \\
\hline 13_Steering Committee & $.514^{* *}$ & $.364^{* *}$ & $.880^{* *}$ & $.496^{* *}$ \\
\hline 5_Project Management & $.575^{* *}$ & $.441^{* *}$ & $.884^{* *}$ & $.551^{* *}$ \\
\hline 21_Vendor partnership & $.572^{* *}$ & $.461^{* *}$ & $.859^{* *}$ & $.506^{* *}$ \\
\hline 4_Clear Goal \& Objectives & $.598^{* *}$ & $.428^{* *}$ & $.442^{* *}$ & $.910^{* *}$ \\
\hline $\begin{array}{l}\text { 7_Appropriate management Of } \\
\text { Expectations }\end{array}$ & $.571^{* *}$ & $.405^{* *}$ & $.414^{* * *}$ & $.892^{* *}$ \\
\hline $\begin{array}{l}\text { 16_BPR (Business Process Re- } \\
\text { engineering) }\end{array}$ & $.582^{* *}$ & $.461^{* *}$ & $.484^{* *}$ & $.881^{* *}$ \\
\hline 12_Dedicated Resources & $.542^{* * *}$ & $.377^{* *}$ & $.446^{* *}$ & $.718^{* *}$ \\
\hline 10_Careful Package Selection & $.561^{* * *}$ & $.368^{* *}$ & $.522^{* *}$ & $.719^{* *}$ \\
\hline
\end{tabular}

\section{FUTURE SCOPE OF THE IDEA}

The author identifies several research directions for the area of ERP research to which this paper is concerned. With respect to future research, a number of different approaches could be considered. Within sector case studies could be used to highlight the critical success factors faced by particular sector. Cross-sector case studies could be used to validate these conclusions as well as to elucidate differences among sectors. Specific industries or organizational sizes might have different organizational characteristics and business requirements for ERP systems and this create a robust research framework and model which may be useful for understanding the critical success factors for the successful ERP implementation and adoption at Indian SMEs. A more in-depth study with multiple cases for consideration could be adopted in order to check whether the CSFs that were identified in this study actually are consistent with what is actually occurring in other country's SMEs environment or not. Following this, an international comparison between CSFs for the ERP implementation at the Indian SMEs could be compared with overseas SMEs.

\section{CONCLUSION}

Implementing an enterprise resource planning requires a wide range of knowledge. Indian SMEs are the backbone of the economy and are today faced with global competition due to LPG (Liberalization, Globalization and Privatizations). Therefore it becomes imperative to look for means of responding to the dynamic markets of growth. Many Indian SMEs do not achieve success in their ERP implementation projects. The aim of this research was to explore the possible CSFs for ERP implementation at Indian SMEs. Previous research on the subject matter was thoroughly explored to form a solid basis for the study.

This study used a theory driven approach to field-test an ERP system implementation model in the Indian ERP market. The results of this research study contribute to the understanding of CSFs for the successful ERP implementation at Indian SMEs. It provide models that can serve as both a framework for practitioners to understand contribution of Critical factors in ERP implementation at Indian SMEs and an avenue to identify and manage ERP customizations for Indian SMEs. Subsequent studies could, for instance, extend the findings to a different context or can examine the issue at a more detailed level. The survey (supported by a comprehensive literature review of the large enterprise) identified twenty three critical 
success factors for the ERP implementation at Indian SMEs. Many surveys have been developed without sound theoretical background. This study identifies the important factors by comparing the mean values of factors. This information may help Indian SMEs to reduce tremendous ERP implementation risks so that they may have more chances to improve their business value with the success of EPR implementation. Such practical implications can be applied to most of the Indian SMEs for a better understanding about the factors that may lead to the success of ERP implementation. This approach should be valuable information for decision makers of Indian SMEs before or during their ERP implementation.

The main basic contributions of this paper are the definition of new constructs associated with the ERP implementation and the development of new multi-item measurement scales for measuring these constructs. The model which proposed was evaluated empirically and was found to be of acceptable reliability and validity. By factor analysis, four critical success factors were identified and they are Approach, Culture, Communication \& Support, Project Management \& Vision, Scope, Goal \& Infrastructure which covers total 23 variables contributing $84.203 \%$ of total variances. These 4 CSF's helps management in implementing ERP system in their organization.

\section{REFERENCES}

[1] Arash shahin, Sahar Sadri \& Roya Gazor, 'Evaluating The Application of Learning Requirement Planning Model in the ERP Project of Esfahan Steel Company' International Journal Of Business \& Management, Vol. 5, No 2, pp 3342, 2010.

[2] Bajwa, D.S., and Garcia, J.E., 'An Integrative Framework for the Assimilation of Enterprise Resource Planning Systems: Phases, Antecedents, and Outcomes' Journal of Computer Information Systems, Vol. 44, (3), pp 81-90, 2004.

[3] Bingi, P., Sharma, M.K, and Godla, J.K 'Critical Issues Affecting an ERP Implementation.' Information Systems Management, Vol. 16, Issue 3, pp.714, 1999.

[4] Brent Snider, Giovani J.C. da silveira and Jaydeep Balakrishnan, 'ERP Implementation at SMEs: analysis of five Canadian cases' International Journal of Operations and production Management, Vol. 29, Issue 1, pp.4 -29, 2009.

[5] Brehm, L., Heinzl, A. and Markus, M.L. 'Tailoring ERP Systems: A Spectrum of Choices and their Implications' Proceedings of the 34th Hawaii International Conference on Information Systems. Outrigger Wailea Resort, Maui. January 3-6, 2001.

[6] Capaldo G., Iandoli L., Rippa P., Mercanti S., troccoli G., 'An AHP Approach To Evaluate Factors Affecting ERP Implementation Success', Proceedings of the World Congress on Engineering and Computer Science, San Francisco, USA, 2008.

[7] Chan-Hsing Lo, Chih-Hung Tsai, and RongKwei Li, 'A Case Study Of ERP Implementation for Opto-Electronics Industry' International Journal of The Computer, Internet and Management, Vol. 13, pp 13-30, 2005.

[8] Daniel E. O'Leary, ' Enterprise Resource Planning (ERP) Systems: An Empirical Analysis of Benefits' Journal of Emerging Technologies In Accounting, Vol.1, pp $63-72,2004$.
[9] Davenport, T.H 'Putting the Enterprise into the Enterprise System.' Harvard Business Review, Vol. 76, Issue 4, pp.121 - 131, 1998.

[10] DeLone, W.H and McLean, E.R 'Information Systems Success: The quest for the dependent variable' Information Systems Research, Vol.3, Issue 1, pp.6095, 1992.

[11] E.W.T. Ngai, C.C.H. Law, F.K.T.Wat, 'Examining the critical success factors in the adoption of enterprise resource planning', Computers Industry, pp 1-17, 2008.

[12] Esteves, J., 'A Benefits Realization Road-map framework for ERP Usage In Small \& Medium Sized Enterprises', Journal of Enterprise Information Management, pp 22-25, 2009.

[13] Gable, G.G.,, Sedera, D., Chan T., 'Enterprise Systems Success: A Measurement Model', International conference on Information systems' Seattle, USA, pp 576-591, 2003

[14] Gable, G.G.,, Sedera, D., Taizan, C., 'Re Conceptualizing Information Systems Success: The Is Impact Measurement Model', Journal of The Association for Information Systems, Vol. 9, pp $1-32,2008$

[15] Gore A. \& Kess P., 'Managing The Impact of ERP Implementation on Organization Structure: A Case Study', The Journal for Practicing Managers, Vol. 31, No 1, pp 1-13, 2007.

[16] Hein Ray Chetcuti, 'ERP implementation: A multi-stakeholder analysis of critical success factors' WICT Proceedings, pp $1-6,2008$.

[17] Holland C. P. and Light B., 'A Critical success factor model for ERP implementation', IEEE Software, pp. 30-36, 1999.

[18] Hong K and Kim Y, 'The Critical success factors for ERP implementation: An organizational fit perspective', Information Management, Vol. 40, No. 1, pp 25-40, 2002

[19] Ifinedo P.,' Enterprise Systems success Measurement Model: A preliminary Study' Journal of Information Technology Management, Vol. 17, Issue 1, pp 14 - 33, 2006.

[20] Ifinedo P., Investigating the Relationship Among ERP Systems Success Dimensions: A Structural Equation Model' Issues In Information Systems, Vol. 8, No 2, pp 399 - 405, 2007.

[21] Ike C. Ehie, Mogens madsen, ' Identifying critical issues in enterprise resource planning (ERP) implementation' Computers In Industry, Vol. 56, pp 545 - 557, 2005, Available online at www.sciencedirect.com .

[22] Jose Esteves-Sousa, John Pastor-Collado, 'Towards the Unification of Critical Success Factors for ERP Implementations', $10^{\text {th }}$ annual Business Information Technology Conference, Manchester, 2000.

[23] Joseph Sarkis, R.P. Sundarraj, 'Managing Large Scale Global Enterprise Resource Planning Systems: A Case Study at Texas Instruments, International Journal Of Information Management, Vol 23, pp 431-442, 2003.

[24] Kale P.T., Banawait S.S, Laroiya S.C., ‘ Performance evaluation of ERP Implementation in Indian SME's' Journal of Manufacturing Technology Management, Vol. 21, pp 758-780, 2010.

[25] Kyung-Kwon Hong, Young-Gul Kim, 'The critical success factors for ERP implementation: an 
organizational fit perspective' Information and Management, Vol. 40, pp 25 - 40, 2002.

[26] Levy M., Powell, P. 'Information System Strategy for small and medium sized enterprises: an organizational perspective', Journal of Strategic Information Systems, Vol 9, pp 63-84, 2000.

[27] Light, B. 'The maintenance implications of the customization of ERP software'. Journal of Software Maintenance and Evolution: Research and Practice; Vol.13: pp 415-429, 2001.

[28] Luo, W. and Strong, D.M. 'A Framework for Evaluating ERP Implementation Choices', IEEE Transactions on Engineering Management, Vol. 51, No 3., pp322-333, 2004.

[29] Mabert,V.A., Soni, A and Venkataramanan, M.A, 'Enterprise resource planning: managing the implementation process'; European journal of operational research, Vol. 146, No 2, pp 302-314, 2003.

[30] Mahadeo Jaiswal, 'ERP enabled Best Business Practices for Competitiveness: Case of Auto Components Manufacturing Industry in India' $6^{\text {th }}$ Annual ISOnEWorld Conference, Las Vegas, 2007.

[31] Markus, M.L., Axline, S., Petrie, D., and Tanis, C 'Learning from the Adapters' Experiences with ERP: problems encountered and success achieved.'

Journal of Information Technology,Vol.15, Issue 4, pp. 245-265, 2000.

[32] McAdam, R, 'Large scale innovationsreengineering methodology in SME's: Positivistic and phenomenological approaches', International Small Business Journal, Vol.20 No 1, pp 33-50, 2002.

[33] Motwani J. Mirchandani D., Madan M. \& Gunasekaran A. 'Successful Implementation of ERP Projects: Evidence From Two Case Studies' International Journal of Production Economics, Vol.75, pp 83-96, 2002.

[34] Nah, F.F.H., Lau, J.L.S., and Kuang, J 'Critical Factors for Successful Implementation of Enterprise Systems.'Business Process Management Journal, Vol. 7 Issue 3, pp. 285 - 296, 2001.

[35] Nah, F.F.H and Delgado, S 'Critical Success Factors for Enterprise Resource Planning Implementation and Upgrade'. Journal of Computer Information Systems, Vol. 47, special issue, pp.99 $-113,2006$

[36] Nah, F.F., Islam, Z., and Tan, M., ' Empirical Assessment of factors Influencing Success of Enterprise Resource Planning Implementations', Journal of Database Management, Vol. 18, No.4, pp 26-50, 2007.

[37] Parijat Upadhyay, Pranab K Dan, ' ERP in Indian SME's: A Post Implementation Study of the Underlying Critical Success Factors' International Journal Of Management Innovation System, Vol. 1, No 2 pp 1-10, 2009.

[38] Park, J., Suh, H., and Yang, H., 'Perceived Absorptive Capacity of Individual Users in Performance of ERP Usage: The Case For Korean Firms', Information \& Managements, Vo. 44, No. 3, pp 300-312, 2007.
[39] Parr, A. and Shanks, G. 'Taxonomy of ERP Implementation Approaches.' Proceedings of the 33rd Hawaii International Conference on System Sciences 93, 2000.

[40] Parr, A and Shanks, G 'A Model of ERP Project Implementation.' Journal of Information Technology, Vol. 15, Issue 4, pp.289-303, 2000.

[41] Poonam Garg, 'Critical Success factors for Enterprise Resource Planning Implementation in Indian Retail industry: An Exploratory study' International Journal of Computer Science and Information Security, Vol. 8, No 2, 2010.

[42] Sarph, J., V., Benson, P., G., Shroeder R., G., ‘ An instrument for measuring the critical factors of quality management', Decision Sciences, Vol. 20, pp 810-829, 1989

[43] Sherry Finney, Martin Corbett, ‘ ERP Implementation: a compilation and analysis of critical success factors', Business Process Management Journal, Vol. 13, No.3, pp 329-347, 2007.

[44] Somers, T.M and Nelson, K 'A taxonomy of players and activities across the ERP project life cycle.' Information \& Management, Vol.41, Issue 3, pp.257-278, 2004.

[45] Staehr, L., 'Assessing Business Benefits From ERP Systems: An Improved ERP Benefits Framework', International Conference on Information Systems, 2007

[46] Sumner M., 'Risk Factors in Enterprise- wide/ERP Projects,' Journal of Information Technology, pp. 317-327, 2000.

[47] Tsai, W. , fan, Y., Leu., J., Chou, L., and Yang, C., 'The Relationship Between Implementation Variables and Performance Improvement of ERP Systems', International Journal of Technology Management, Vol. 38, No.4, pp 350-373, 2007.

[48] Umble, E.J., Haft, R.R., and Umble, M.M 'Enterprise resource planning: Implementation procedures and critical success factors.' European journal of operational research, Vol. 146, Issue 2, pp. $241-257,2003$.

[49] Vineet Kansal, ' Systematic Analysis for InterRelation of Identified Critical Success Factors In Enterprise Systems Projects', Contemporary Management Research, Vol. 3, No 4, pp 331 346, 2007

[50] Wei, C.C., Chien C.F., and Wang M.J.J, ' An AHP-based Approach to ERP System Selection', International Journal Of Production Economics, Vol. 96, No. 1, pp 47-62, 2005.

[51] Yusuf, Y., Gunasekaran, A., and Wu, C 'Implementation of Enterprise Resource Planning in China.' Technovation, Vol.26, Issue 12, pp.1324 1336, 2006.

[52] Zach, O., Olesen, D.H., 'ERP System Implementation in Make-to-order SMEs: An Exploratory Case Study', $44^{\text {th }}$ Hawaii International Conference on System Sciences, Kauai, Hawaii USA, 2011.

[53] Zhang, Z., Lee, M.K.O., Zhang, L., and Huang, X 'A framework of ERP systems implementation success in China: An empirical study.' International Journal Production Economics, Vol. 98. Issue 1, pp. $56-80,2005$. 